\title{
SMEs Access to Financial Services: Bankers’ Eye
}

\author{
Evelyn Mweta Richard, Neema Geoffrey Mori \\ University of Dar es Salaam Business School, Dar es Salaam, Tanzania
}

\begin{abstract}
This paper reports Tanzanian bankers' reasons for not giving SMEs the amount they request as loans to finance their businesses. Open ended interviews were used to collect primary data from eight interviews in six commercial banks that serve SMEs and which have been in operation for more than five years. Secondary data was obtained from different documents like World Bank reports, brochures and websites of visited banks to mention the few. Findings show that sectors which are perceived as too risky by banks, poor documentation by borrowers which make banks unable to assess their creditworthiness, lack of understanding by SMEs themselves as to why they are doing businesses they do, lack or very limited knowledge on financial management by SMEs, lack of awareness of different products offered by different banks, stagnant businesses as well as lack of proper securitiries to cover their loans are reasons behind banks reluctant to provide loans to SMEs. Findings clearly show that it is still difficult for new SMEs to access finance from banks in Tanzania. It is critical for existing SMEs to put their houses in order to the level that is acceptable by banks if they need to approach banks for loans. Banks in Tanzania need to review their policies on the maximum amount of loans to SMEs to reflect the market demands. At the moment, new SMEs should not have much hope of getting finance assistance from most banks. Further, training institutions should continue educating SMEs on relevant aspect that are important to lenders and lastly, the government should consider providing guarantee to SMEs sectors that are perceived as too risky by banks just like the ongoing initiatives in the agriculture sector.
\end{abstract}

Keywords: SMEs’ financing, commercial banks, Tanzania

\section{Introduction}

The availability of external finance for small and medium enterprises (SMEs) is a topic of significant research interest to academicians and an important issue to policy-makers around the globe. This is because finance is one of the key elements in determining growth and survival of SMEs in both developed and developing countries (ACCA, 2009). Access to finance allows SMEs undertake productive investments and contribute more to economic development and poverty alleviation (Beck, Demirgüç-Kunt, Laeven, \& Maksimovic, 2006). Without finance, SMEs cannot expand to compete in international markets or even strike business linkages with larger firms. Access to finance however, has always been mentioned by SMEs both existing and potential operators, as the most serious barrier to business expansion and or business start-up (Finscope, 2007; Olomi, Mori, Mduma, \& Urassa, 2008).

Evelyn Mweta Richard, Ph.D. candidate, Assistant Lecturer, Finance Department, University of Dar es Salaam Business School. Neema Geoffrey Mori, Ph.D. candidate, Assistant Lecturer, Finance Department, University of Dar es Salaam Business School. Correspondence concerning this paper should be addressed to Evelyn Mweta Richard, University of Dar es Salaam Business School, P.O. Box 35046, Dar es Salaam, Tanzania. E-mail: eve@udbs.udsm.ac.tz; neema18@yahoo.com. 
In Africa and Tanzania in particular, SMEs traditionally have faced difficulty in obtaining formal credit or equity (Olomi et al., 2008). As a consequence, most of them finance their activities using own funds, loans from friends and family, money lenders, relatives, rotating savings and credit groups (Beck \& Demirguc-Kunt, 2006; Mori et al., 2009). The amount of capital that is raised through these methods is limited and insufficient to sustainably finance growing SMEs. Due to lack of finance for most SMEs, banks and other Financial Institutions (FIs) in Tanzania are trying to launch a number of initiatives to provide them with better financial products that are tailored to their needs (Olomi et al., 2008).

The government has also taken a number of measures to reform the financial sector and promote lending to SMEs (URT, 2001, 2003). Regardless of the reforms by the government, Banks and other FIs which geared at enhancing SMEs' access to capital, there is still a gap between what is claimed to be available and what SMEs report to face when trying to access finances. Overall, availability of finance is still perceived as a major problem for small enterprises. Previous studies show that SMEs are more constrained in their operation and growth than large enterprises (Beck, 2007; Beck \& Demirguc-Kunt, 2006, 2008). In developing countries, access to and cost of finance are rated by SMEs as major growth constraint than any other characteristic of the business environment (Beck, 2007). The higher financing obstacles reported by SMEs as compared to large enterprises are also reflected in their financing patterns.

To the researchers' knowledge, apart from Torre, Peria, and Schmukler (2008) who analyzed SMEs financing drivers and obstacles from bankers' perception in Chile and Argentina, and Fatoki and Smit (2011) who concentrated at constraints to credit access by new SMEs in South Africa: A supply-side analysis, most other empirical studies in the globe have analyzed access to finance mostly from the demand side (ACCA, 2009; Beck \& Demirguc-Kunt, 2008). Following Olomi et al. (2008), this paper is targeted at empirically examining factors from banks' side that influence them supply funds to SMEs. Clear understanding of these factors is very important so as to establish what can be done to efficiently assist SMEs.

The paper is organized as follows: The next section gives a review of the literature on the subject matter followed by research methodology. Results of the study and discussion are presented next. Lastly, the paper concludes and provides implications of the results.

\section{Literature Review}

SMEs are the emerging private sector in poor countries and thus form the base for private sector-led growth. Access to finance however, has continuously been reported as a leading obstacle to SMEs businesses' undertakings and so as growth (Beck, 2007). Literature further shows that, SMEs are more adversely affected by this obstacle (Olomi, Chijoriga, \& Mori, 2007).

The theory of asymmetric information argues that it is difficult to distinguish good from bad borrowers (Auronen, 2003) which normally results in adverse selection and moral hazards problems. The agency theory further, explains that the interest of the principal (lender) and the agent (borrower) diverge because both parties have different utility functions. This situation normally makes the principal and the agent prefer different actions because of the different risk preferences (Eisenhardt, 1989). These two theories explain the banks' lending behavior given the existence of the agency problem as well as the fact that lenders are imperfectly informed about the characteristics of borrowers (Obamuyi, 2007). 
In Tanzania, SMEs have several options for financing their investments. Examples of these options include loans from commercial banks; funds from semi financial institutions such as savings and cooperative associations (SACCOs); and informal financial institutions such as money lenders (Mori et al., 2009; Olomi et al., 2008). Despite these options, most SMEs opt for semi and informal financing because of their accessibility.

There are several studies which look at SME accessibility to finance in both developed and developing countries. A study by Torre et al. (2008) shows that banks in Chile and Argentina have begun to target SMEs due to the significant competition in the corporate and retail sectors. These banks perceive the SMEs market as highly profitable and with good prospects. Authors show that, banks in these countries are aware of challenges which arise in working with SMEs but they believe that cooperation with SMEs is a step forward for the banks to offer financing profitably. Fraser (2004) quoted in Obamuyi (2007) as well as Beck et al. (2006) among other things observed that size and age influence financing relationship of lenders to borrowers. A study by Beck (2007) shows that SMEs in developing countries are more constrained by financing obstacles because of the weaknesses in the financial and legal systems. He analyzed more than 70 developing countries and concluded that governments have roles of building appropriate institutions, providing the regulatory framework and undertake market-friendly activist policies in order to reduce financing obstacles for SMEs. The author also cautions on the too much involvement of governments in SME financing. Fatoki and Smit (2011) observed that in South Africa factors internal to SMEs such as managerial competency, collateral, networking and business information and those external to SMEs such as macro-economy, the legal environment, ethical perception, crime and corruption constraint new SMEs to access credits.

A study by Olomi et al. (2008) shows three main groups of constraints limiting SMEs access to finance in Tanzania. The capacity of the SMEs themselves in terms of their low level of knowledge and skills, under-developed business culture, lack of separation of business from family or personal matters, limited documented credit history and tendency for them not to explore all financing options available. The second constraint has to do with the limited capacity for working with SMEs, including limited number of competent personnel and limited experience leading to design of simple, straight jacket products whose risks are low and easy to assess. The third group relates to deficits in the enabling environment in terms of laws that over protect borrowers at the expense of lenders, absence of national identification system and credit reference bureaus. The literature shows that SMEs face huge obstacles in accessing finance from banks. Most of the obstacles established are from SMEs' perspective. This paper provides an insight of these obstacles from bankers' eyes.

\section{Methodology}

The study used case study approach in collecting data. When this study was conducted there were 15 Banks that serve SMEs. Letters were sent to all the banks requesting them to participate in the study. Six banks out of the 15 accepted to participate and thus constitute the sample for this study. The required information was collected from both secondary and primary sources. Secondary sources used were relevant documents from libraries, respective banks' websites, World Bank reports and various brochures from visited banks. Primary information was collected through open ended interviews. Bank officers dealing with SMEs' loan appraisal and administration with working experience of five years or more were targeted for the interviews. The time element was very important in order to tap rich information (Yin, 2003). A total number of these officers was requested 
and it was established that only 12 officers qualified for the study. Eight officers were available and therefore interviewed. Questions covered background information of the bank, financial services offered to SMEs, maximum amount offered and reasons behind, loan appraisal, approval and administration procedures for both new and existing borrowers as well as key items to qualify borrowers for loans. Also, default rate trend for the last five years and reasons behind.

All the information collected was separately recorded through hand written by the two researchers. Later, the information was typed as a word process document, shared by the two researchers and finally combined to form one document. Each case was recorded separately (according to the order of interviews) following the specific study objective. Banks' names are not disclosed given the agreement between the respective banks and the researchers. The case information however, was sent to interviewees for their comments and validation. Content analysis was used to analyze the cases and establish reasons provided by banks that make them not able to give additional financial support to SMEs.

\section{Findings and Discussion}

\section{Profile, and Services Offered}

Six commercial banks which are included in this study offer financial services to SMEs and are a mixture of small and large banks. Three of them are locally owned and the rest are foreign owned. These banks have been operating in Tanzania for an average of ten years, so they have gained experience with the Tanzania market and specifically, the SME sector. All common services offered are business loans of short and long term maturity; business training and advice; and deposit services. Other services are like money transfers and overdrafts.

Most of the lending related financial services offered by these banks to SMEs are almost the same. These are short term loans to a maximum of TZS 25 million on average and are given for the period of less than 12 months; long term loans (on average of TZS 100 million) which range from a period of two to ten years; business training which mostly is provided for free to those applicants who show interest of borrowing from those banks; and business advices which are provided during the whole loaning period. One commercial bank goes an extra mile and conducts an awareness forum free of charge for all relevant stakeholders once a year. This is done for the purpose of assisting SMEs develop business networks. It must be understood that some banks serve individual borrowers while others serve a group of borrowers. There are those that do not deal with micro businesses while others do, and some deals with groups of micro businesses and not individuals. There are also those who serve only on-going businesses while others serve both on-going and start-ups businesses. Banks that serve micro businesses and the start-ups businesses however are still very few.

Most banks offer loans to almost all legal businesses in all sectors except those that are perceived as very high risky. The risky perception is mostly assessed through the inability of the bank to establish the respective business's cash flows either due to the complexity in the nature of the business or lack of enough and reliable information concerning the business. Some banks assess it through the nature of management of the given business. For instance, local transport business in Tanzania is perceived highly risk by some of the banks because it is not managed professionally. The most suffering sectors happen to be the small scale mining as well as small scale fishing. Few banks, however, mentioned that they can consider these businesses if they request the loan as a group but not as individuals. 
All banks perform thorough assessment of SMEs before considering them as potential customers. During the assessment factors that are considered (which are almost common to all banks that offer loans to on-going businesses) are: Information concerning the ability of the business to operate as a going concern; information on the trend of business turnovers as well as all other transactions; information on the business investment in terms of total value and premises; information on the duration at which the business has been in operations; information concerning business's cash flows and information concerning collateral for the loan.

Most banks claimed that SMEs do still face problems with understanding what business they want to do and why; cannot keep proper documentation of their trading businesses; they lack business skills as well as collateral for the funds they request. Banks therefore, do conduct business training and counselling services. Interviewees mentioned that most of the SMEs benefited from these trainings and counselling services. One interviewee said:

Sometimes SMEs just ask for loans but they do not need them. After attending our trainings some of them realize that they have lots of money at their disposal and they don't need a loan at that particular time, what they actually need to do is to reorganize their business records and keep them properly.

It was also found out that some banks go further and assist SMEs improving their borrowness ability. One interviewee explained that:

You may find an applicant with very reputable business but lacks enough collateral, or has good business and collateral but lacks proper business records. These applicants are assisted by the bank in improving whatever is lacking in order to enable them qualify for the loans.

It was also found out that few banks can offer loans to on-going SMEs without asking for the financial statements. One interviewee put this as follows:

We know that it is very difficult to get proper financial statements and business plan from these people and therefore, we rely on discussions (interview) with the borrower, visiting their business premises and assess their business activities.

The duration for assessment differs from one bank to another. Some take only few days while others take weeks. The difference in timing is due to the availability of all required relevant information from borrowers. Few banks stressed that timely release of funds to qualified borrowers is very critical because they believe that delaying the funds is actually not assisting the borrower. One interviewee said:

Traders need the cash very fast, if you delay the process, you actually not assisting them, but make them fail achieving their targets.

Banks further monitor their customers very closely to ensure that they do perform well and repay the loans as required. This was clearly put by interviewees as:

The bank does not offer loans to SMEs clients and leaves them there. We continue monitoring their performance through out the loaning period and even after.

Monitoring and supervision is done through visiting SMEs business premises and check their business records, check their bank accounts and follow up their repayments. These findings indicate how banks strive in dealing with asymmetric information and agency problems.

\section{Reasons for SMEs Failing to Access Additional Funds}

Findings provide a clear insight on reasons that make most SMEs face difficulties in accessing additional funds. Maximum loan limit by banks is one reason. It was found out that few FIS provide a big amount of short 
term loans to SMEs. Most banks' maximum limit for short term loans is lower than those needed by SMEs. Lack of awareness and information gap is another reason. Many SME operators are not fully aware of what is available in the financial sector. Many of them go to a certain bank because they have been told by friends or they have seen other people going there. They do not do proper research to find out how and where they can get what they want. SMEs' perception of banks is another problem.

Most SMEs perceive banks as grant providers. They forget that banks are also doing business. SME operators need to understand that banks perceive most of SME businesses as highly risk and will likely charge high interest to cover for the risk and make profit. Another reason is lack of knowledge on financial management by SMEs. Sometimes SMEs request for loans which they really don't need or is over and above what they need. For example, an SME operator may require USD 120 thousand to buy a machine, but, when the loan officers do their analysis they find out that this client does not need that amount for the machine. The bank will offer the operator what is really needed and not what is asked. This sometimes makes SMEs think that the bank refuses to give them the loan requested while in actual sense the bank offers them what is needed.

Moral hazards problem is another issue. Many SME operators who borrow working capital from banks, usually do not use the loan according to the reasons presented in their request. One interviewee said that:

There was a time we gave a client a loan to buy merchandise for his store. When he got the money he used it for other reasons. After one month, we start charging the instalments in his account, only to find out he did not buy the merchandise as he stated in the application. The other business he invested the money in, did not pay well as expected. We ended up taking his collateral.

This habit discourages banks from providing additional loans to SMEs. Finally are the business prospects. Most FIs perform an impact assessment to establish achievements made by the business through the use of the loan given before considering giving additional loans. Some banks do maintain a successful relationship with their customers and enable them get additional funds for their businesses. One interviewee explained this as follows:

One of our success stories is that, there is one SME which initially borrowed TZS 4 millions and now the business is getting TZS 20 millions. When this client started, the collateral he had was not worthy getting TZS 20 millions. As time passes the client improved the business and the bank assisted him in formalizing some of his assets which allowed the business to get TZS 20 millions. In this situation the client can rarely default.

Good business performance is therefore very important when SMEs think of asking for additional funds. It is very possible that when FIS perform impact assessment they realise that most SMEs do not qualify for additional loans. Our findings show that most factors are borrowers oriented.

\section{Conclusion and Recommendation}

\section{Conclusion}

It was established that banks are sceptical in giving loans to not only very risky businesses but also new businesses. They are keen when assessing the creditworthiness of SMEs while dealing with asymmetric information problems. Factors that contribute to limited financial assistance in the form of loans to SMEs by banks are: lack of enough evidence from SMEs that enable banks perform the required analysis, lack of SMEs' awareness as to why they do the business they do, limited knowledge on financial management as well as unfaithfully records especially of utilizing funds different from what was requested for. Other factors established were lack of collateral, poor performance and stagnant SMEs’ businesses. 


\section{Recommendations}

Findings clearly show that it is critical for SMEs to put their houses in order to the level that is acceptable by banks if they need to approach banks for loans. Banks in Tanzania also need to review their policies on the maximum amount of loans to SMEs to reflect the market demands. At the moment, new SMEs should not have much hope of getting finance assistance from most banks. Further, training institutions should continue educating SMEs on relevant aspects that are of important to lenders and lastly, the government should consider providing guarantee to those SMEs' sectors perceived as too risky by banks just like the ongoing initiatives in the agriculture sector.

\section{References}

ACCA. (2009). Access to finance for small and medium sized enterprise sector: Evidence and conclusion. Retrieved March 2010, from http://www.cpaaustralia.com.au/cps/rde/xbcr/cpa-site/ACCA-CGA-CPAA_JointReport_201009.pdf

Auronen, L. (2003). Asymmetric information: Theory and applications. Paper presented in the seminar of Strategy and International Business at Helsinki University of Technology, May 21.

Beck, T. (2007). Financing constraints of SMEs in developing countries: Evidence, determinants and solutions. Retrieved January 2010, from http://arno.uvt.nl/show.cgi?fid=95654

Beck, T., \& Demirguc-Kunt, A. (2006). Small and medium-size enterprises: Access to finance as a growth constraint. Journal of Banking \& Finance, 30(11), 2931-2943.

Beck, T., \& Demirguc-Kunt, A. (2008). Access to finance: An unfinished agenda. World Bank Econ Review, 22(3), 383-396.

Beck, T., Demirguc-Kunt, A., \& Maksimovic, V. (2004). Bank competition and access to finance: International evidence. Journal of Money, Credit and Banking, 36(3), 627-648.

Beck, T., Demirgüç-Kunt, A., Laeven, L., \& Maksimovic, V. (2006). The determinants of financing obstacles. Journal of International Money and Finance, 25(6), 932-952.

Berger, A. N., \& Udell, G. F. (2006). A more complete conceptual framework for SME finance. Journal of Banking and Finance, 30(11), 2945-2966.

Eisenhardt, K. M. (1989). Agency theory: An assessment and review. Academy of Management Review, 14(1), 57-74

Fatoki, O. O., \& Smit, A. V. A. (2011). Constraints to credit access by new SMEs in South Africa: A supply-side analysis. African Journal of Business Management, 5(4), 1413-1425.

Finscope. (2007). Finscope national survey on access and demand for financial services in Tanzania. Dar es Salaam: Financial Sector Deepening trust.

Majocchia, A., Bacchiocchib, E., \& Mayrhofer, U. (2005). Firm size, business experience and export intensity in SMEs: A longitudinal approach to complex relationships. International Business Review, 14, 14, 20.

Mori, N., Richard, E., Isaack, A., \& Olomi, D. (2009). Access to finance for SMEs in Tanzania. In D. Olomi (Ed.), African entrepreneurship and small business development: Context and process (Vol. 1). Dar es Salaam: Otme Company Ltd..

Obamuyi, T. M. (2007). An exploratory study of loan delinquency among small and medium enterprises (SMEs) in ONDO State of Nigeria. Labour and Management in Development Journal, 8(1), 1-11

Olomi, D. (2008a). Tanzania: Developing a strategy for rural financial services: Financial sector deepening trust. Financial Sector Deepening Trust (FSDT).

Olomi, D. (2008b). Performance of microfinance institutions and impact to socio-economic development: A case of Zanzibar. Dar es Salaam: International Labour Organization.

Olomi, D., Chijoriga, M., \& Mori, N. (2007). Mapping of obstacles for establishing and expanding business in Tanzania. Dar es Salaam University of Dar es Salaam.

Olomi, D., Mori, N., Mduma, E., \& Urassa, G. (2008). Constraints to access to capital by Tanzanian SMEs. Dar es Salaam: REPOA.

Torre, A., Peria, M., \& Schmukler, S. (2008). Drivers and obstacles to banking SMEs: The role of competition and the institutional framework. World Bank.

UDEC. (2005). Inventory study of SME Sector in Tanzania. Dar es Salaam: University of Dar es Salaam.

URT. (2001). National Microfinance Policy. Ministry of Finance. Government report. Retrieved from http://www.tanzania.go.tz/pdf/nationalmicrofinancepolicy.pdf

URT. (2003). Small and Medium Enterprises (SME) Development Policy. Ministry of Industry and Trade. Government report. Retrieved from http://www.tanzania.go.tz/pdf/smepolicy.pdf

Yin, R. K. (2003). Applications of case study research. Sage Publications. 